oxide on the developing hamster embryo. Can J Physiol Pharmacol 1979;51:1229-32.

28 Vieira E. Effect of the chronic administration of nitrous oxide $0.5 \%$ to gravid rats. Brit J Anaesth 1979;51:283-7.

29 Vieira E, Cleaton-Jones P, Austin JC, Moyes DG, Shaw R. Effects of low concentrations of nitrous oxide on rat fetuses. Anesth Analg 1980;59:175-7.

30 Corbett TH, Cornell RG, Endres J, Millard RI. Effects of low concentration of nitrous oxide on rat pregnancy. Anesthesiology 1973;39:299-301.

31 Ross WT Jr, Cardell RR. Effects of halothane on the ultrastructure of rat liver cells. Am J Anat 1972;135:5-22.

32 Chang LW, Dudley AW, Lee YK, Katz J. Ultrastructural studies of the heptocytes after chronic exposure to low levels of halothane. Exp Mol Pathol 1975;23:35-42.

33 Basford AB, Fink BR. The teratogenicity of halothane in the rat. Anesthesiology 1968;29:1167-73.

34 Hughes HC, Lang CM. Hepatitis necrosis produced by repeated administration of halothane to guinea pigs. Anesthesiology 1972;36:466-71.
35 Smith BE, Gaub ML, Moya F. Investigations into the teratogenic effects of anesthetic agents: the fluorinated agents. Anesthesiology 1965;26:260-1.

36 Smith BE, Usubiaga LE, Lehrer SB. Cleft palate induced by halothane anesthesia in C-57 black mice. Teratology 1971;4:242.

37 Axelsson G, Rylander R. Exposure to anesthetic gases and spontaneous abortion response bias in a postal questionnaire study. Int J Epidemiol 1982;11:250-6.

38 Axelsson G, Rylander R. Validation of questionnaire reported miscarriage malformation and birth weight. Int J Epidemiol 1984;13:94-8.

39 Rajhans GS, Brown DA, Whaley DA, Wong L, Guirguis SS. Evaluation of occupational exposure to waste anesthetic gases in Ontario hospitals. Ann Occup Hyg 1989;33:27-45.

Accepted 22 January 1990

\section{Radiograph atlas of pneumoconiosis: Professor Qi-Guoxing}

This unique collection of chest $x$ ray films shows all the classic changes that none of us in the west can hope to see in a lifetime; indeed they would be difficult to find even by an exhaustive search of the film archives of all the departments of occupational chest disease. Each film is quite well reproduced and is accompanied by a diagram showing the relevant abnormalities and a brief note in English as well as in Chinese describing the changes and giving both the occupation of the subject and the International Labour Office classification of the changes shown by the $x$ ray film. Two hundred and sixty seven separate conditions are dealt with in this way and are followed by 80 films showing combinations of conditions and progression. Everyone who is interested in occupational lung disease will enjoy owning this book and will refer to it from time to time. It can be obtained from the author for a draft or international money order for $\$ 30$ plus $\$ 15$ postage to: Professor Qi-Guoxing, Shanxi Provincial Institute of Labour, Health, and Occupational Disease, Taiyuan City 030012, Peoples Republic of China.

Unfortunately the text book on pneumoconiosis by the same author has not been translated into English. P C ELMES Dawros House, St Andrew's Road, Dinas Powys, $S$ Glamorgan CF6 $4 H B$. 